Original Research Paper

\title{
Pengolahan Ikan Hasil Tangkapan Nelayan Menjadi Abon untuk Meningkatkan Pendapatan Keluarga Nelayan di Desa Ketapang Raya, Lombok Timur
}

\author{
Moehamad Anggian Ibnu Abdi Wangsa', Muhammad Sofiadi ${ }^{1 *}$, Amanda Kerina1, Yola Ardita ${ }^{1}$, Abdul \\ Syukur ${ }^{2}$ \\ ${ }^{1}$ Fakultas Ekonomi Dan Bisnis Universitas Mataram, Mataram, Indonesia. \\ ${ }^{2}$ Pendidikan Biologi, FKIP, Universitas Mataram, Mataram, Indonesia.
}

https://doi.org/10.29303/jpmpi.v3i2.905

Sitasi: Wangsa, M. A. I. A., Sofiadi, M., Kerina. A., Ardita, Y., \& Syukur, A. (2021). Pengolahan Ikan Hasil Tangkapan Nelayan Menjadi Abon untuk Meningkatkan Pendapatan Keluarga Nelayan di Desa Ketapang Raya, Lombok Timur. Jurnal Pengabdian Magister Pendidikan IPA, 4(3)

\section{Article history}

Received: 19 Juli 2021

Revised: 31 Juli 2020

Accepted: 19 Agustus 2021

*Corresponding Author: Muhammad Sofiadi, Fakultas Ekonomi Dan Bisnis Universitas Mataram, Mataram, Indonesia;

Email:

muhammadsofiadi2@gmail.com
Abstract: Abon adalah salah satu jenis olahan untuk membuat makanan berbahan dasar daging menjadi awet dan bernilai ekonomis tinggi. Pengolahan ini merubah tekstur daging menjadi berserabut dengan cara disuwir dan menggunakan jenis daging dari unggas, sapi dan ikan. Teknik pemasakan dilakukan dengan pengosengan menggunakan minyak yang sedikit atau bisa disebut teknik pan frying. Tujuan dari program ini untuk meningkatkan pendapatan keluarga nelayan dan memberi referensi untuk mengoptimalkan hasil tangkapan nelayan di Desa Ketapang Raya. Cara yang diterapkan, dengan mengadakan pelatihan pengolahan abon ikan pada masyarakat Desa Ketapang Raya. Pengolahan diawali dengan pengukusan kemudian ikan disuwir hingga bertekstur serabut, setelah itu daging ikan yang berserabut dicampur dengan bumbu dan dioseng hingga kering. Metode pelaksanaan pelatihan abon ikan ini dilakukan dengan cara FGD (Fokus Group Diskusi), dimana pemateri menjelaskan tahapan pengolahan abon ikan dengan mempraktekan secara langsung dan peserta dapat berinteraksi secara verbal dengan pemateri selama proses kegiatan. Program ini menggunakan Metode kualitatif dengan pendekatan kualitatif deskriptif. Untuk pengolahan data dilakukan dengan cara penyajian data dan penarikan kesimpulan. Hasil dari program ini adalah yang awalnya nelayan menjual ikan tangkapannya dengan harga 25 ribu per $\mathrm{kg}$, setelah diolah menjadi abon harga menjadi 250 ribu per kg. Untuk memproduksi abon ikan ini dilakukan secara berkelompok, dalam tiap kelompok setidaknya membutuhkan 3 orang tenaga kerja dan hal tersebut cukup berpengaruh terhadap penyerapan tenaga kerja di Desa Ketapang Raya. Produk ini dipasarkan di Kedai - Kedai yang ada di pantai Lungkak yang notabene merupakan lokasi wisata dan memudahkan dalam pemasaran produk, selain itu dipasarkan juga melalui media sosial untuk memperluas jangkauan promosi produk. Output dari program ini adalah terbentuknya masyarakat mandiri yang mampu memproduksi abon ikan sehingga dapat menghasilkan produk yang bernilai ekonomis tinggi serta menyerap tenaga kerja yang berimbas pada peningkatan pendapatan keluarga nelayan.

Keywords: Pengolahan Ikan Laut; Abon; Keluarga Nelayan; Desa Ketapang Raya. 


\section{Pendahuluan}

Kabupaten Lombok Timur adalah salah satu dari 7 (tujuh) kabupaten/kota yang ada di Provinsi Nusa Tenggara Barat dengan panjang pantai kabupaten Lombok Timur adalah $220 \mathrm{~km}$ dan luas $+1.074 \mathrm{~km}^{2}$. Dari kondisi ini dapat diketahui kabupaten Lombok Timur memiliki pontensial perikanan yang dapat di kembangkan sumberdaya perikanan, baik itu perikanan budidaya maupun perikanan tangkap. Dapat diketahui bahwa potensi sumber daya lestari kabupaten Lombok Timur pertahun yaitu 11.400 ton/ tahun yang dapat terdiri dari potensi sumber daya ikan pelagis 4.567 ton/tahun serta sumberdaya ikan demersal 6.843 ton/tahun. Pengembangan pemanfaatan sumberdaya tersebut masih dalam lingkup skala yang kecil, yaitu penangkapan yang dilakukan oleh para masyarakat atau nelayan masih relatif tradisional, (Dinas Perikanan dan Kelautan Lombok Timur, 2004). Perkembangan dari produksi perikanan desa ketapang raya dari tahun ketahun mengalami suatu perubahan, yaitu terkadang naik dan terkadang turun. Perkembangan ini dapat dipengaruhi oleh beberapa faktor, seperti faktor biologi, faktor unit penangkapan, faktor permintaan dan ketersediaan.

Ikan merupakan salah satu hasil yang dikonsumsi masyarakat karena merupakan sumber protein yang mudah dicerna dan kadar lemak yang rendah yang sangat bermanfaat bagi kesehatan. Tetapi, ikan cepat mengalami pembusukan yang diakibatkan oleh enzim dan mikroorganisme. Biasanya untuk membuat ikan tahan lama umumnya dilakukan proses pengolahan pasca panen, salah satunya yaitu dibuat menjadi abon ikan.

Desa Ketapang Raya adalah salah satu Desa penghasil ikan laut yang mampu mendukung perekonomian masyarakat. Produksi ikan laut dapat diolah menjadi berbagai produk olahan ikan yang salah satunya yaitu menjadi abon ikan yang mampu mendukung sektor perekonomian keluarga nelayan serta masyarakat Desa Ketapang Raya. Oleh karena itu, dari produksi ikan laut dan diolah menjadi abon ikan, mampu menjadi harapan Desa untuk membuka lapangan kerja dan mengatasi masalah pengangguran yang terjadi khususnya di Desa Ketapang Raya.

Abon ikan sendiri merupakan makanan yang terbuat dari olahan daging ikan yang disuwirsuwir kemudian ditambahkan dengan bumbu- bumbu dan selanjutnya dilakukan pengosengan. Tampilan umumnya berwarna coklat terang hingga kehitam-hitaman. Abon tampak seperti serat-serat kapas, karena didominasi oleh serat-serat otot yang mengering yang disuwir-suwir. Karena kering, abon biasanya awet disimpan berminggu-minggu hingga berbulan-bulan dalam kemasan yang kedap udara. Walaupun mereka mampu membuat atau memproduksi abon ikan tersebut, mereka terkendala dalam memasarkan produk olahan tersebut.

Hal ini juga yang menjadi permasalahan di Desa Ketapang Raya, dimana masyarakat memiliki kendala dalam pemasaran dari hasil pengolahan ikan menjadi abon. Seperti halnya masyarakat masih minim dalam penggunaan media sosial dan masih sangat awam tentang pentingnya branding dalam memasarkan sebuah produk. Karena gambaran umum desa Ketapang Raya ini adalah, mayoritas penduduknya bermata pencaharian sebagai nelayan yang tingkat perekonomian dari kalangan menengah ke bawah, dan tingkat pendidikannya relatif rendah. Oleh karena itu, mereka terkendala dalam melakukan kegiatan pemasaran atau promosi produk. Dimana saat ini segala sesuatu sangat lekat dengan digitalisasi, sementara masyarakat atau nelayan desa ketapang raya sebagian besar belum melek terhadap penggunaan teknologi dan sistem yang digital.

Berdasarkan realita di atas, kami mengusulkan gagasan untuk melakukan pelatihan pengolahan ikan menjadi abon dan bekerjasama dengan salah satu UMKM yang berada di Desa Ketapang Raya yaitu UMKM "Generasi Kreatif" serta membantu mereka dalam memasarkan produk tersebut melalui media sosial. Pelatihan abon ikan ini bertujuan untuk mengedukasi nelayan dalam memaksimalkan potensi hasil tangkapan ikan mereka menjadi abon yang notabene memiliki nilai ekonomis lebih tinggi. Kemudian usaha membantu memasarkan produk abon ikan yang diproduksi oleh nelayan ini, merupakan salah satu upaya untuk mendorong peningkatan pendapatan keluarga nelayan di desa Ketapang Raya melalui promosi produk abon ikan di media sosial dan pemberian label atau branding guna produk abon ikan yang diproduksi dapat dikenal masyarakat secara luas. Yang diharapkan berdampak pada meningkatnya pendapatan keluarga nelayan desa Ketapang Raya. 


\section{Metode}

\section{A. Persiapan}

Tahapan dari persiapan program

Pengolahan Abon Ikan yang telah dilakukan oleh

Tim KKN Tematik Universitas Mataram Periode

2021 di Desa Ketapang Raya yaitu di antaranya:

1) Persiapan Materi tentang pengolahan Abon Ikan seperti: Pengenalan dan peningkatan pengetahuan dalam keterampilan mengelola ikan menjadi Abon untuk menunjang perekonomian masyarakat Desa Ketapang Raya, menentukan model pengolahan abon ikan dan menunjang pengembangan perekonomian secara terpadu dan berkelanjutan.

2) Persiapan perlengkapan dan bahan untuk menunjang keberlangsungan pengolahan abon ikan untuk mendukung perekonomian masyarakat Desa Ketapang Raya.

3) Persiapan tempat dan konsep untuk pengolahan abon ikan dalam bentuk pemanfaatan fasilitas yang sudah tersedia.

4) Persiapan desain model promosi dan brand abon ikan dari hasil pengolahan bersama masyarakat desa Ketapang Raya.

B. Pelaksanaan Pengolahan Abon Ikan di Desa Ketapang Raya

Adapun metode pelaksanaan kegiatan

$(\mathrm{KKN})$ kuliah kerja nyata yaitu seperti:

1) Metode pengolahan abon ikan kepada ibu- ibu PPK dan masyarakat desa Ketapang Raya yaitu menggunakan metode Pendekatan secara langsung yaitu praktek/ latihan langsung dengan cara sosialisasi dalam kegiatan pengolahan abon ikan yang sesuai dengan tujuan program untuk meningkatkan perekonomian masyarakat yang sesuai protokol kesehatan.

2) Menggunakan metode Fokus Group Diskusi (FGD) yaitu metode yang digunakan yang berdasarkan diskusi yang dilakukan secara sistematis dan terarah mengenai pengolahan abon ikan.

C. Waktu dan Tempat Pelaksanaan

Program KKN Tematik Era New Normal dengan tema pariwisata dan lingkungan dan bermitra dengan UMKM "Generasi Kreatif" yang dilaksanakan pada tanggal 21 Juni hingga 5 Agustus 2021 yang berlokasi di Desa Ketapang
Raya, Kecamatan Keruak, Kabupaten Lombok Timur.

D. Alat dan Bahan

Adapun alat-alat yang dibutuhkan dalam program abon ikan yaitu Kompor, Tabung gas, Wajan, Sutil, Cobek, Piring,dan Cutter. Bahanbahan yang digunakan pada pengolahan program abon ikan ini yaitu, Ikan $1 \mathrm{~kg}, 500$ gram Minyak goreng, 20 biji Cabe, 1/4 Lengkuas, 1/4 Jahe, 250 gram Gula merah, 400 gram Santan kara, $1 / 4$ Kunyit, 15 gram Merica, 1/4 Bawang merah, 1/4 Bawang putih, 1 sendok makan Garam halus, dan 25 gram Penyedap rasa.

\section{E. Proses Pembuatan Produk}

Produksi inovasi yang diciptakan adalah produk Abon Ikan yang bahan baku utama berasal dari hasil laut di Desa Ketapang Raya. Produk yang kaya akan vitamin yang terkandung pada ikan dapat memudahkan semua orang dapat mengkonsumsi dengan mudah. Adapun proses dalam pembuatan produk abon ikan yaitu pertama siapkan bahan baku berupa Ikan segar, Potong dan belah ikan menjadi beberapa bagian, Pisahkan daging dan tulang, Siapkan panci sedang yang telah berisi air untuk mengukus ikan, Masukkan ikan ke dalam panci untuk siap dikukus, Nyalakan Kompor dengan api sedang dan ikan siap di kukus, Kukus ikan dengan waktu 25 menit dengan api sedang, Setelah 25 menit, angkat ikan ke wadah untuk siap di suir,

Kemudian, siapkan cobek dan bumbu untuk abon ikan, Haluskan ikan dan semua bumbu ke dalam cobek hingga tekstur halus, Siapkan wajan dan sutil untuk menggoreng ikan yang sudah di campur dengan bumbu, Masukkan 5 sendok makan minyak goreng ke dalam wajan dengan api sedang, Masukkan ikan yang sudah tercampur bumbu dan siap untuk di goreng, Goreng ikan dengan api sedang hingga berubah warna kecoklatan, Ikan yang sudah berubah warna kecoklatan dan tekstur sudah mengering, Siapkan piring untuk tempat abon ikan yang sudah matang, Siapkan kemasan atau wadah abon ikan untuk dipasarkan, dan terakhir Ikan siap dipasarkan atau dinikmati secara langsung. 


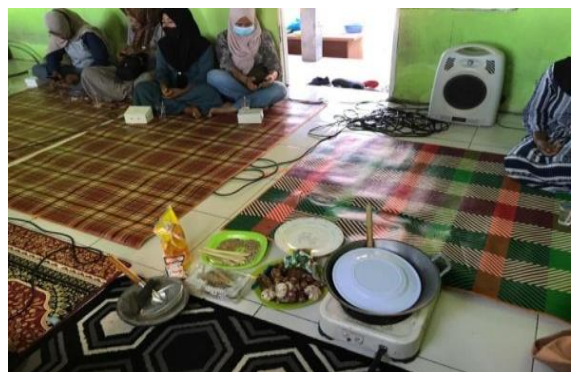

Gambar 1. Bahan - Bahan Produk Abon Ikan

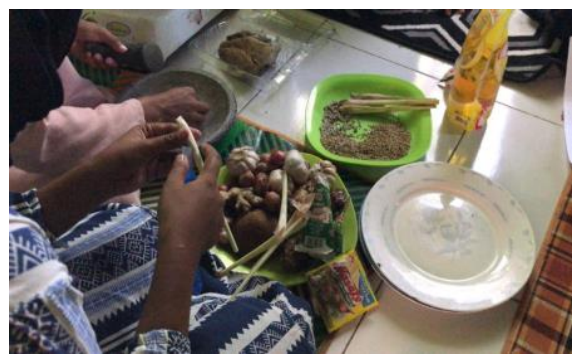

Gambar 2. Persiapan Pembuatan produk Abon Ikan F. Metode

Kegiatan program ini adalah dengan menggunakan metode pendekatan kualitatif dengan pendekatan kualitatif deskriptif. Karena, dapat menyajikan gambaran dengan cara detail mengenai situasi. Pendekatan Kualitatif merupakan metode penelitian yang sesuai pada filsafat postpositivisme, yang digunakan untuk meneliti suatu kondisi obyek yang alamiah, dimana peneliti adalah sebagai instrumen kunci, teknik pengumpulan data dilakukan dengan triangulasi (gabungan), analisis data bersifat induktif/kualitatif, dan hasil penelitian lebih menekankan makna daripada generalisasi.

\section{Hasil dan Pembahasan}

Pelaksanaan kegiatan Kuliah Kerja Nyata (KKN) Tematik Era New Normal dilaksanakan sejak pelepasan tanggal 21 juni 2021 sampai dengan 5 Agustus 2021. Kegiatan KKN ini berlokasi di desa Ketapang Raya, Kecamatan Keruak, Kabupaten Lombok Timur. Dengan jarak tempuh sekitar $60 \mathrm{~km}$ dari Pusat kota Mataram.

Dari hasil observasi permasalahan yang ditemukan dikalangan masyarakat Desa Ketapang Raya adalah kurang jelinya melihat peluang yang ada.

\section{1) Survey Potensi}

Potensi dari Desa Ketapang Raya adalah sumber daya alam dan sumber daya manusia yang dimiliki oleh suatu daerah sebagai modal dasar yang perlu untuk dikelola dan dikembangkan untuk keberlangsungan serta perkembangan desa. Potensi sumber daya ekonomi yang dimiliki oleh Desa Ketapang Raya adalah adanya hasil laut yang kaya dalam bidang perikanan. Oleh Karena itu potensi ini mendukung perekonomian desa dalam bidang perekonomian.

\section{2) Pembuatan Produk Abon Ikan}

Produk adalah Kegiatan dalam pengolahan abon ikan ini bertujuan untuk mendukung perekonomian Desa Ketapang Raya dengan menambahkan nilai jual ikan dengan cara mengolah menjadi abon ikan yang tahan lama dan tinggi akan kandungan gizi pada ikan. Sehingga semua orang mampu mengkonsumsi ikan kapan saja dengan mudah.

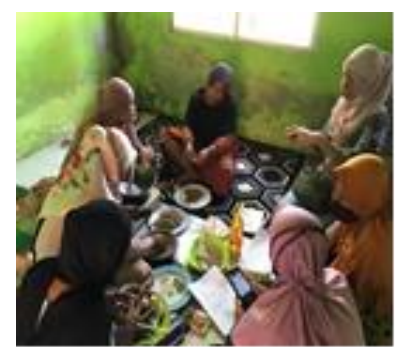

Gambar 3

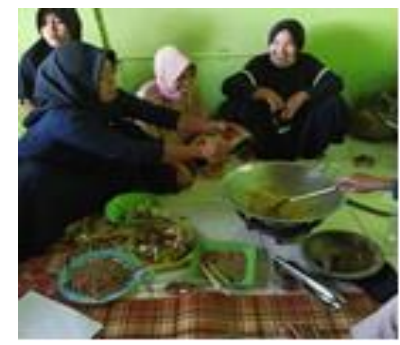

Gambar 4
Gambar 3, 4. Proses Pembuatan Abon Ikan

Adapun beberapa ciri-ciri ikan yang segar:

- Mata

Mata ikan yang segar tampak terang dan jernih dengan warna hitam di bagian tengahnya. Permukaannya pun terasa menonjol dan kenyal saat diraba. Sebaliknya, mata ikan yang sudah tidak segar tampak mengerut dan keruh. Bagian mata yang seharusnya berwarna putih kekuningan juga berubah warna menjadi kemerahan.

- Insang

Angkatlah penutup insang pada sisi kepala ikan. Ikan yang baru ditangkap memiliki insang berwarna merah yang tampak bersih dan segar. Semakin merah warna insang, maka semakin baik kulitnya. Insang berwarna kecoklatan atau keabuan dengan bagian insang yang tampak terpisah satu sama lain menandakan bahwa kualitas ikan telah menurun. 


\section{- Kulit dan Sisik}

Salah satu cara mudah memilih ikan segar adalah dengan mengamati warna kulit dan sisiknya. Kulit ikan berkualitas baik tampak menggeliat dengan warna yang terang. Sisiknya pun masih menempel dengan kuat pada badan ikan dan tidak mudah lepas saat ditarik. Sementara itu, ikan berkualitas rendah memiliki kulit dan sisik yang tampak kusam. saat dipegang, sisiknya juga mudah terlepas.

\section{- Daging ikan}

Daging ikan yang segar tampak jernih dengan warna translusen yang cerah. Beberapa jenis ikan memiliki warna daging putih terang, tapi ada pula jenis yang memiliki warna berbeda. Apa pun jenis ikan yang anda pilih, pastikan bahwa warnanya cerah dan tidak kusam. Ikan segar memiliki tekstur yang lembut, tapi cukup kenyal sehingga dapat kembali ke bentuknya semula setelah ditekan. Seluruh dagingnya juga menempel kuat pada tulang. Berbeda dengan ikan segar, daging ikan yang kualitasnya menurun berwarna kusam. Teksturnya pun berubah menjadi lebih lunak.

\section{- Perut}

Cara lain untuk memilih ikan segar adalah dengan menekan bagian perutnya. Perut ikan yang segar terasa kenyal saat ditekan dan dapat kembali ke bentuk semula. Sementara itu, ikan berkualitas rendah memiliki tekstur perut yang lunak. Isi perutnya juga dapat terburai dengan mudah saat anda menekannya.

\section{- Bau}

Ikan berkualitas baik memiliki bau khas yang segar dan ringan. Bau yang keluar dari ikan segar tidak mengganggu penciuman ataupun terasa aneh. Sebaliknya, bau amis yang menyengat menandakan bahwa ikan tidak lagi segar. Ikan tersebut juga telah dibiarkan terlalu lama dalam suhu ruang dan telah mulai mengalami pembusukan.

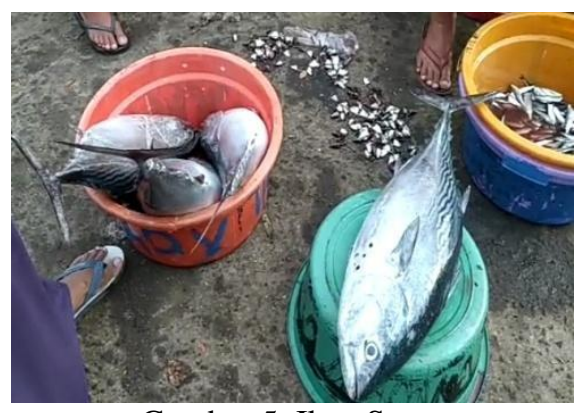

Gambar 5. Ikan Segar

\section{3) Pengemasan Produk}

Pengemasan adalah suatu material pembungkus produk yang memiliki fungsi untuk menampung, melindungi, mengidentifikasi,dan mempromosikan produk. Fungsi pengemasan tidak hanya berguna untuk melindungi produk, tetapi juga berfungsi sebagai alat pemasaran dan juga membangun identitas brand serta meningkatkan penjualan. Pada dasarnya kemasan produk merupakan salah satu hal yang sangat penting dan juga tidak bisa dipisahkan dari proses pemasaran dan distribusi pada suatu produk.

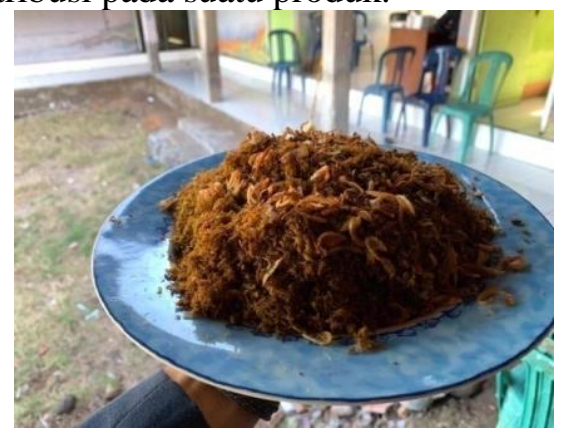

Gambar 7. Abon Ikan

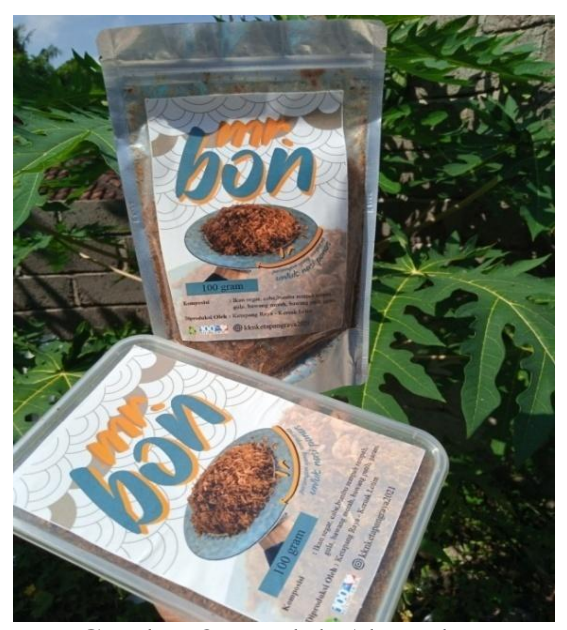

Gambar 8. Produk Abon Ikan 


\section{4) Pemasaran Produk}

Pemasaran yang digunakan dalam produk ini menggunakan analisis STP (Segmenting/ segmentasi pasar, Targeting/ target pasar, dan Positioning) dan promosi:

\section{a. Segmenting}

Segmentasi dalam pemasaran adalah pemetaan konsumen berdasarkan karakteristik, daya beli, kebutuhan yang berbeda - beda di dalam situasi pasar tertentu. Pengertian segmentasi pasar menurut ahli; Gary Amstrong, Segmentasi pasar adalah kegiatan membagi pasar yang luas menjadi berpetak-petak sesuai kebutuhan dan karakteristik konsumen. Tujuanya adalah supaya perusahaan bisa melahirkan produk yang memang dibutuhkan oleh mereka.

Segmentasi pasar yang diberlakukan dalam pemasaran produk ini yaitu membagi konsumen yang berdasarkan kebutuhannya dalam mengkonsumsi. Disini produsen membuat dua ukuran kemasan produk dengan wadah dan berat yang berbeda.

\section{b. Targeting / Target pasar}

Targeting adalah suatu tindakan dalam menilai ketertarikan serta minat dari berbagai segmen pasar, selanjutnya menentukan segmen pasar yang akan dijadikan sebagai target pasar. Target pasar dari Abon Ikan untuk semua kalangan masyarakat ibu-ibu rumah tangga, mahasiswa mahasiswi, pegawai instansi atau kantor, serta wisatawan lokal maupun mancanegara yang berkunjung di tempat wisata seperti Lungkak beach yang terdapat di Desa Ketapang Raya serta lokasi pasar lainnya. Alasan kami menargetkan daerah wisata sebagai lokasi pasar karena, produk ini dirancang sebagai bentuk "oleh-oleh" atau buah tangan yang dapat dibawa konsumen ketempat asalnya setelah melakukan kunjungan ke lokasi wisata tersebut, selain itu menjadikan tempat wisata sebagai tempat memasarkan memberikan kami kemudahan dalam mengenalkan produk, karena mobilitas masyarakat atau konsumen cenderung lebih tinggi di tempat tersebut sehingga pengenalan produk lebih mudah untuk dilaksanakan.

\section{c. Positioning}

Positioning adalah upaya untuk menetapkan posisi produk dalam menghadapi suatu persaingan pasar. Dalam melaksanakan suatu proses dalam pemasaran kami berupaya untuk menanamkan kesan baik pada konsumen yaitu dengan menjadikan produk Abon Ikan ini sebagai abon Ikan Khas Desa Ketapang Raya yang memberikan nilai edukasi mengenai kearifan lokal khas dari Desa ini. Untuk itu, langkah awal yang kami lakukan pada pemasaran abon ikan ini yaitu dengan memanfaatkan media sosial menitipkan ke toko-toko, pasar-pasar, pedagang yang ada dilingkungan desa ketapang Raya dengan bekerjasama dengan Bumdes. Serta bekerjasama dengan UMKM Generasi Kreatif Desa ketapang Raya. Selain itu kami mengandalkan tagline produk dengan kalimat "Pasangan sempurna Untuk Nasi Panas" yang menekankan bahwa produk olahan abon Ikan yang kami produksi sebagai olahan makanan yang pas untuk dijadikan lauk nasi panas. Sehingga tagline tersebut menjadi positioning kami agar produk abon Ikan ini diasosiasikan oleh konsumen sebagai pasangan yang sempurna untuk nasi panas mereka.

\section{d. Promosi}

Promosi untuk memperkenal produk abon Ikan ini, kami berupaya menggunakan berbagai media sosial alternatif dalam promosi yang dapat meminimalisir biaya. Melalui media sosial seperti facebook, Line, Instagram, dan whatsApp. Selain itu, kami memanfaatkan event CFD (Car Free Day) dan bazar dalam setiap acara penting yang diselenggarakan untuk mendekatkan diri kepada konsumen sehingga produk ini banyak disukai dan dikenal masyarakat luas.

\section{e. Pengantaran Produk}

Pemasaran secara online sangat mendukung pada saat ini. Setelah promosi dilakukan dengan cara online melalui berbagai media sosial seperti Whatsapp, Instagram, dan facebook. Selanjutnya proses pengantaran produk ke konsumen dari hasil pemesanan secara online yang telah dilakukan. Adapun pengantaran produk yang sesuai dengan pesanan yaitu di daerah Mataram, Lombok Barat. Untuk pengantaran produk selanjutnya akan dilakukan secara luas hingga ke berbagai daerah. Memanfaatkan marketplace serta platform dengan memerhatikan promosi yang lebih luas dan tersebar secara global. 


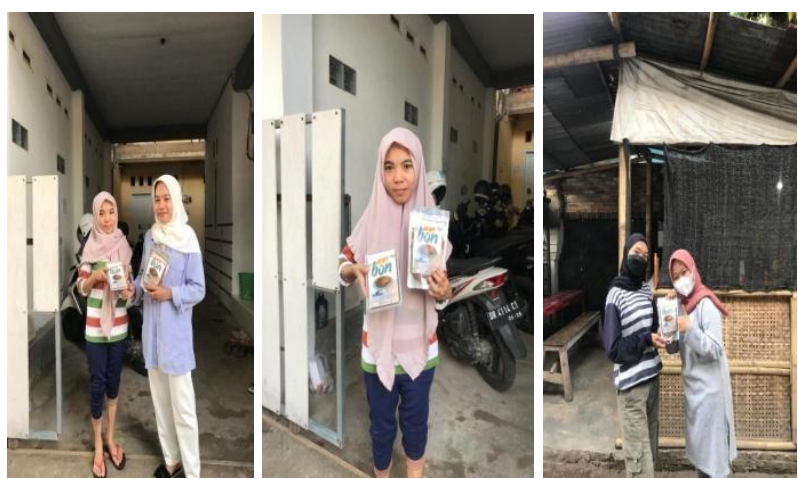

Gambar 9. Pengantaran Produk Abon Ikan Ke Konsumen

\section{f. Pembukuaan}

Pembukuaan penting untuk mencatat dan mengetahui informasi dari hasil penjualan dan pengeluaran yang terjadi selama periode pemasaran serta pada saat produksi produk. Selain itu, biayabiaya operasional masuk ke dalam pembukuaan untuk mengetahui tingkat biaya - biaya yang dikeluarkan selama produksi. Adapun tujuan dari pembukuaan ini yaitu untuk membantu dalam proses kegiatan berwirausaha. Sehingga dapat disimpulkan bahwa layak atau tidaknya suatu usaha dapat diketahui mulai dari pencatatan dari hasil yang diperoleh sesuai dengan harapan atau tujuan yang ingin dicapai.

Pembukuaan dilakukan pada saat produksi produk hingga pengantaran suatu produk kepada konsumen yang memperoleh hasil yang cukup maksimal. Tujuan dan harapan kedepannya yaitu memasarkan produk ini untuk lebih luas dan menyeluruh secara global dengan memanfaatkan platform serta marketplace yang dapat membantu para produsen dalam memasarkan produk di masa yang canggih ini dengan memanfaatkan media digital. Selain itu, konsumen juga mudah dalam memperoleh informasi produk dari media maya yang sangat memudahkan dalam berbelanja sesuai yang diinginkan. Oleh karena itu, pembukuan dalam hal ini penting dan memiliki peran yang besar dalam suatu kegiatan berwirausaha.

\section{Kesimpulan}

Berdasarkan hasil dari rangkaian program yang dilakukan, dari pelatihan abon ikan hingga kegiatan membantu memasarkan produk abon ikan tersebut. Masyarakat terlihat antusias dan menerima dengan baik kegiatan pelatihan abon ikan dan pemasaran produk abon yang dilakukan oleh mahasiswa KKN UNRAM. Sehingga segala rangkaian kegiatan yang dilakukan tersebut membuat masyarakat memiliki alternatif untuk memaksimalkan hasil tangkapan ikan mereka dan mampu meningkatkan pendapatan keluarga mereka.

\section{Ucapan Terima Kasih}

Terima Kasih kepada Fakultas Ekonomi Dan Bisnis Universitas Mataram, kemudian Terimakasih juga kami haturkan kepada DPL kami yaitu Bapak Dr.Drs. Abdul Syukur,M. Si dan terakhir kami ucapkan terimakasih kepada Mitra yang telah membantu yaitu UMKM (Generasi Kreatif ) Desa Ketapang Raya. Karena atas bantuan dan partisipasinya serta bimbingannya, KKN TEMATIK 2021 program Pariwisata dan Lingkungan dapat berjalan dengan lancar.

\section{Daftar Pustaka}

Armyn, M., Alldi, R., \& Pratama Mauludana Afif, Juliyono, Safitri Indah, F. N. (2019). Produksi Abon Ikan Lele Sebagai Alternatif Usaha untuk Meningkatkan Perekonomian Masyarakat Desa Pelutan. AJIE - Asian Journal of Innovation and Entrepreneurship, 04(September), 199-206.

Bul. 2021. "Kelompok KKN Tematik Unram Latih Masyarakat Desa Ketapang Raya Membuat Olahan Hasil Laut" Suara NTB, 5 Agustus 2021.

Dzulmawan Muhammad, Geo Laode, G. A. (2019). Analisis Nilai Tambah Pengelolaan Abon Ikan Tuna Di Kelurahan Mata Kecamatan kendari Kota Kendari. Jurnal Agribisnis Dan Ilmu Sosial Ekonomi Pertanian, 4(2), 29-34.

Mahrus, Abdurrazif, Z. D., Wiwik, F., Nur, A., Rizk.i, A., \& Darusman, A. (2021). Pembuatan Abon dari Ikan Tuna Sebagai Salah Satu Alternatif Wirausaha Baru di Desa Batu Nampar Selatan. Jurnal Pengabdian Magister Pendidikan IPA, 4, $2-5$.

Materi Abon ikan https://id.wikipedia.org/wiki/ Abon_ikan. Diakses pada tanggal 8 Agustus 2021.

Materi Ikan Segar. https://perikanan.pamekasankab. go.id/tips-memilih-ikan-segar.html. Diakses Pada 02 Agustus 2021.

Materi metode penelitian https://www.gurupendidikan. co.id/metode-penelitian-kualitatif/. Diakses pada tanggal 8 Agustus 2021. 
Materi Pemasaran produk. https://accurate.id/marketingmanajemen/pengertian-kemasan-produk. Diakes pada tanggal 8 Agustus 2021.

Materi Pemasaran produk. https://midtrans.com/ $\mathrm{id} / \mathrm{blog} /$ segmenting-targeting-positioning.

Diakses pada Tanggal 2 Agustus 2021

Rahmi Sutiya Nurbayu. Hubungan Patron-Client Dan Ritual Petik Laut. Universitas diponegoro. 